\title{
Morphogenetic and structural characteristics of xaraes palisadegrass submitted to cutting heights ${ }^{1}$
}

\section{Braulio Maia de Lana Sousa ${ }^{2}$, Domicio do Nascimento Júnior ${ }^{2}$, Carlindo Santos Rodrigues², Hélida Christhine de Freitas Monteiro ${ }^{2}$, Sila Carneiro da Silva ${ }^{3}$, Dilermando Miranda da Fonseca ${ }^{2}$, André Fischer Sbrissia ${ }^{4}$}

\author{
1 Financiado pelo CNPq. \\ 2 Departamento de Zootecnia - UFV, Viçosa, MG. \\ ${ }^{3}$ Departamento de Zootecnia - USP/ESALQ, Piracicaba, SP. \\ ${ }^{4}$ Departamento de Produção Animal e Alimentos - UDESC, Lages, SC.
}

\begin{abstract}
The objective of this work was to evaluate the morphogenetic and structural characteristics of xaraes palisadegrass submitted to three cutting heights $(15,20$ and $25 \mathrm{~cm}$ ) when the sward reached 95\% of light interception during regrowth. The experiment was carried out according to a complete randomized block design with three replications. The sward surface height under the cutting condition of 95\% of light interception was very homogeneous with values around $30 \mathrm{~cm}$. The increase in cutting height reduced the leaf elongation rate and the number of live leaves but increased stem elongation rate. As the cutting criterion was the same, before the intense competition for light, the variation in the cutting severity had a small influence on the morphogenetic and structural characteristics of this grass. In the summer, due to the better growth conditions, the plants presented a higher tissue renewal, which was characterized by a higher leaf elongation rate, reduced leaf lifespan and leaf senescence rate when compared to the other season of the year. Under intermittent defoliation conditions, the regrowth of xaraes palisadegrass can be interrupted at a sward height of $30 \mathrm{~cm}$ (frequency) keeping a residual height of $15 \mathrm{~cm}$.
\end{abstract}

Key Words: Brachiaria brizantha, ecophysiology, grazing management, light interception, morphogenesis, sward height

\section{Características morfogênicas e estruturais do capim-xaraés submetido a alturas de corte}

RESUMO - Este trabalho foi realizado com o objetivo de avaliar as características morfogênicas e estruturais do capimxaraés submetido a três alturas de corte $(15,20$ e $25 \mathrm{~cm})$ quando atingidos 95\% de interceptação de luz durante a rebrotação. O experimento foi conduzido segundo delineamento de blocos completos casualizados com três repetições. A altura do dossel na condição de corte de $95 \%$ de interceptação de luz mostrou-se homogênea, com valores próximos a 30 cm. A elevação na altura de corte reduziu a taxa de alongamento de folhas e o número de folhas vivas, mas aumentou a taxa de alongamento de colmos. Como o critério para a realização dos cortes foi o mesmo, antes da competição intensa por luz, a variação na severidade de corte pouco influenciou as características morfogênicas e estruturais dessa gramínea. No verão, devido às melhores condições de crescimento, as plantas apresentaram maior renovação de tecidos, fato caracterizado pela maior taxa de alongamento foliar, pela menor duração de vida da folha e taxa de senescência de folhas comparativamente à outra estação do ano. Em condições de desfolhação intermitente, a rebrotação do capim-xaraés pode ser interrompida aos $30 \mathrm{~cm}$ de altura do dossel (frequência) mantendo-se $15 \mathrm{~cm}$ de altura de resíduo.

Palavras-chave:altura do dossel, Brachiaria brizantha, ecofisiologia, interceptação luminosa, manejo do pastejo, morfogênese

\section{Introduction}

The xaraes palisadegrass (Brachiaria brizantha) was released in 2002 by EMBRAPA - Gado de Corte to provide another forage option to form pastures in Central Brazil (Valle et al., 2003). Despite the wide adaptation and the use of marandu palisadegrass in Brazil, the diversification of forage plants on pastures can minimize the risks and the dependence on a single species and/or cultivar, as well as improving herbage production and distribution throughout the year (Pedreira, 2006). However, improvement in the productive system by the introduction of new forage plants 
is even greater when appropriate management practices are employed within the limits of tolerance and resistance to defoliation of the plant in various environments.

Recent researches in Brazil (Giacomini et al., 2009a, b; Da Silva et al., 2009), markedly on the genera Brachiaria and Panicum, indicate that the $95 \%$ of light interception by the sward can be considered as the ideal moment to interrupt regrowth. The use of light interception, already studied for temperate climate grasses (Korte et al., 1982), has been successfully applied for tropical grasses under intermittent stocking (Da Silva \& Nascimento Júnior, 2007). This condition presented a high relationship with the sward surface height (Carnevalli et al., 2006; Barbosa et al., 2007; Sousa et al., 2010), indicating that sward height targets could be used as a practical and useful guide to tropical grazing management purposes.

Based on this new approach, Pedreira et al. (2007) evaluated xaraes palisadegrass, in Piracicaba, São Paulo, submitted to different grazing strategies under intermittent stocking, and showed that the interception of 95\% of incident light corresponded to a sward surface height of approximately $30 \mathrm{~cm}$. Nevertheless, the available information on growth and development dynamics of xaraes palisadegrass as well as morphophysiological changes in response to variations in severity of defoliation is still limited.

Thus, this work was proposed with the main objective of verifying changes in morphogenetic and structural characteristics in Brachiaria brizantha (A. Rich.) Stapf. cv. Xaraes submitted to three cutting heights in different seasons of the year.

\section{Material and Methods}

The experiment was carried out in the Departamento de Zootecnia of the Universidade Federal de Viçosa (UFV), in Viçosa, MG, Brazil, (2045' S, 42 $51^{\prime}$ W, 651 m), with Brachiaria brizantha cv. Xaraes from January $4^{\text {th }}$ to October $17^{\text {th }}$, 2008. According to Köppen System, the climate in the region is Cwa, subtropical, with well defined dry (winter) and rainy (summer) seasons. During the experimental period, information related to climatic conditions (Figure 1) was obtained from the meteorological station of UFV, which is located about $1,000 \mathrm{~m}$ from the experimental site. The monthly water soil balance (Figure 2) related to the experimental period was calculated using $50 \mathrm{~mm}$ water storage capacity (Thornthwaite \& Mather, 1955).

The soil is classified as Inceptic Hapludults, with loamclay texture (EMBRAPA, 2006). Average soil chemical characteristics (Raij et al., 1986) for the 0-20 cm layer were: $\mathrm{pH}$ in $\mathrm{H}_{2} \mathrm{O}=5.2 ; \mathrm{P}=1.2$ (Mehlich-1) and $\mathrm{K}=22 \mathrm{mg} / \mathrm{dm}^{3}$; $\mathrm{Ca}^{+2}=2.5 ; \mathrm{Mg}^{+2}=0.5 ; \mathrm{Al}^{+3}=0.1 ; \mathrm{H}+\mathrm{Al}=4.13 ;$ cation exchange capacity $=3.16 \mathrm{cmol} / \mathrm{dm}^{3}$ and sum of bases $=43 \%$.

Three cutting heights were evaluated (15, 20 and $25 \mathrm{~cm})$, all performed consistently when the swards intercepted $95 \%$ of incident light during regrowth. The $15 \mathrm{~cm}$ cut was considered very severe and represented a high level of forage utilization, $20 \mathrm{~cm}$ was considered as an intermediate cut, and $25 \mathrm{~cm}$ a more lenient cut. The cutting heights were allocated to experimental units $\left(12 \mathrm{~m}^{2}\right)$ according to a complete randomized block design with three replications.

Xaraes palisadegrass was fertilized with $50 \mathrm{~kg} / \mathrm{ha}$ of phosphorus (simple superphosphate), $200 \mathrm{~kg} / \mathrm{ha}$ of nitrogen

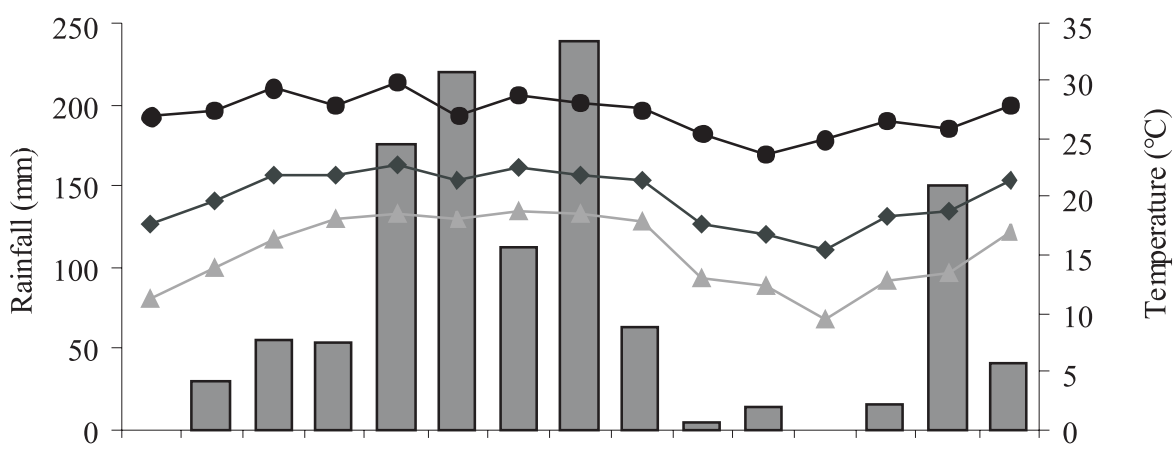

Aug Sep Oct Nov Dec Jan Feb Mar Apr May Jun Jul Aug Sep Oct

Months

$\square$ Rainfall $(\mathrm{mm}) \longrightarrow$ Average temperature $\left({ }^{\circ} \mathrm{C}\right)-$ Maximum temperature $\left({ }^{\circ} \mathrm{C}\right)-$ Minimum temperature $\left({ }^{\circ} \mathrm{C}\right)$

Figure 1 - Monthly rainfall and minimum (filled triangle), average (filled square), maximum (filled circle) daily air temperature during the experimental period.

R. Bras. Zootec., v.40, n.1, p.53-59, 2011 


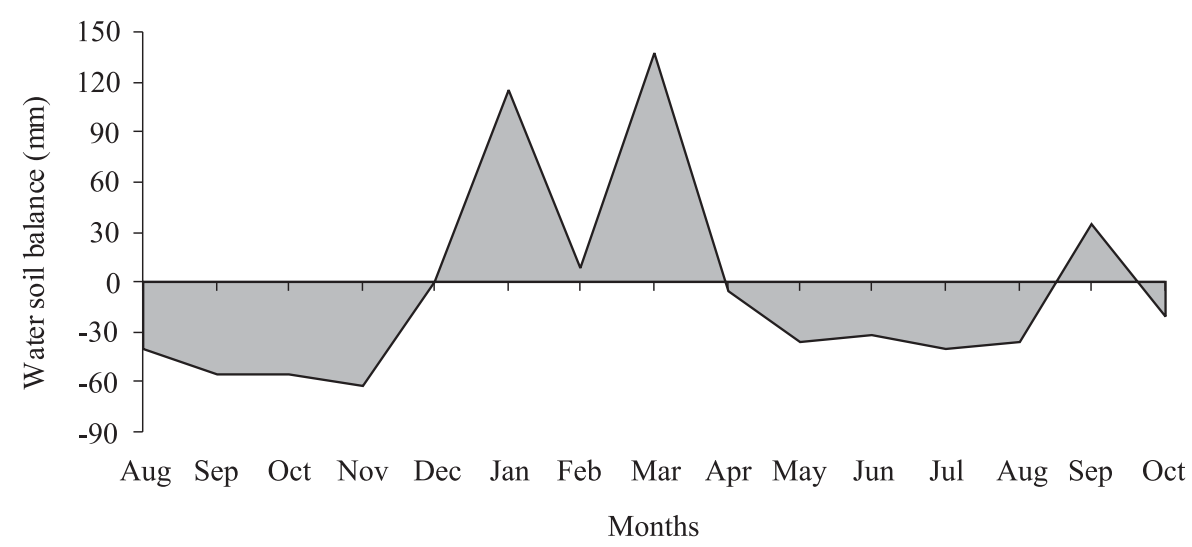

Figure 2 - Monthly water soil balance during the experimental period.

(ammonium sulfate) and $100 \mathrm{~kg} / \mathrm{ha}$ of potassium (potassium chloride). Potassium and nitrogen were split in three and four applications, respectively, and phosphorus was applied in a single one.

Because the plants were under free growth, three cuts were performed at $15 \mathrm{~cm}$ from the soil (lower cutting height) from September to December 2007 aiming at adapting the studied plant to defoliation. In order to increase tillering activity, the first three doses of fertilization were applied concurrently to the cuts. On $1 / 4 / 2008$, a new cut was carried out in all plots at $15 \mathrm{~cm}$ from the ground level, a procedure that set the beginning of the evaluations. After the first cycle of regrowth, each plot was cut to its respective cutting height. The last dose of nitrogen was applied in February.

Evaluation of light interception, foliage area index, and foliage angle in relation to the ground (leaves, stem and dead material) in the plots was performed immediately after the cut and during regrowth (every five days) using a Plant Canopy Analyzer LAI 2000 (LI-COR ${ }^{\circledR}$ ), in two random points per experimental unit. At each point, a reading above the sward, and five on the soil surface (under the sward) were taken.

The sward surface height was measured at five points in each experimental unit, concurrently with assessments of light interception, using a transparency sheet as a reference and a ruler. At each point of the four sides of the transparency sheet, the highest and the smallest height values were recorded, obtaining the average height per point. The experimental unit average corresponded to the average of the readings in the five points of each plot.

Right after each cut, ten tillers per plot were randomly chosen and marked with a colored wire to assess, twice a week, the leaf blade and pseudostem (stem and leaf sheaths) elongation and leaf senescence. Based on this information, leaf appearance rate (leaf/tiller.day), leaf elongation rate (cm/tiller.day), leaf senescence rate ( $\mathrm{cm} /$ tiller.day), stem elongation rate (cm/tiller.day), phyllochron (days/leaf), final leaf blade length $(\mathrm{cm})$, number of live leaves (leaves/tiller), and leaf lifespan (days/leaf) were calculated. Tiller population density (tillers $/ \mathrm{m}^{2}$ ) was estimated by counting all live tillers in two $0.25 \mathrm{~m}^{2}$ areas $(0.25 \mathrm{~m} \times 1.00 \mathrm{~m})$ per experimental unit, randomly chosen after each cut.

Data from the morphogenetic and structural variables were collected from January to June 2008 and they were organized in away that representative means (weighted for the length of cutting cycles) were generated as it follows: summer (January, February and March); and autumn (April, May and June). By the end of the autumn, evaluations of morphogenetic and structural characteristics finished. However, as most plots had not reached the condition of 95\% interception of incident light, the evaluations related to light interception, sward surface height, foliage area index, and foliage angle in relation to the ground continued to be assessed until this condition was reached, which occurred only in the beginning of spring. Thus, for these variables, both in post and pre-cut, the data were grouped as it follows: summer (January, February and March) and autumn-winter-early spring (from April to October).

The data were submitted to variance analysis using the Mixed Procedure of SAS ${ }^{\circledR}$ (Statistical Analysis System) version 8.2 for Windows ${ }^{\circledR}$. The entire data set was tested to ensure that the basic prerogatives of the variance analysis were met. For choosing a matrix of variance and covariance, the Akaike Information Criterion (Wolfinger, 1993) was used. Therefore, it was possible to detect the effects of the main variance causes (cutting height and seasons) and the interaction between these causes. The effects of the cutting height of the seasons and their interactions were considered as fixed effects, and the 
effect of blocks and their interactions were considered as random effects (Little et al., 2000). Means among treatments were estimated by using the LSMEANS and compared by PDIFF using the t-Student test at 5\% significance.

\section{Results and Discussion}

The increase in the cutting height resulted in a higher light interception in early regrowth period, certainly because of the greatest remaining foliage area and the lowest foliage angle in relation to the ground level (more horizontal orientation of the canopy) (Table 1). Taller cuts removed less forage, leaving a greater remaining foliage area. Thus, the greater proportion of leaves in relation to stems, as well as a longer remaining leaf length favored a more horizontal structure of the leaves immediately after cutting (Table 1). Plants with leaves horizontally arranged intercept more light with less leaf area compared to those with erect leaves, i.e., the spatial arrangement of the canopy leaf area presents a marked effect in the amount of light intercepted and, consequently, in the photosynthetic potential of plant communities (Marshall, 1987). These results corroborate those available in the literature for $P$. maximum cv. Mombaca (Carnevalli et al., 2006; Da Silva et al., 2009), P. maximum cv. Tanzania (Barbosa et al., 2007; Difante et al., 2009a, b), B. brizantha cv. Xaraes (Pedreira et al., 2007), B. brizantha cv. Marandu (Trindade et al., 2007), B. decumbens cv. Basilisk (Braga et al., 2008), and Andropogon gayanus cv. Planaltina (Sousa et al., 2010), which show changes in sward structure in response to the grass management strategies.

In autumn-winter-early spring, plants presented foliages with a more vertical disposition because of a greater foliage angle after cutting (Table 2). This arrangement could favor

Table 1 - Post and pre-cutting sward structure in xaraes palisadegrass cut at different heights reaching 95\% of light interception

\begin{tabular}{lcccc}
\hline Variable & \multicolumn{3}{c}{ Cutting height $(\mathrm{cm})$} & \multirow{2}{*}{ SEM } \\
\cline { 2 - 4 } & 15 & 20 & 25 \\
\hline & \multicolumn{5}{c}{ Post-cut } \\
Light interception (\%) & $73 \mathrm{c}$ & $85.3 \mathrm{~b}$ & $88.9 \mathrm{a}$ & 0.44 \\
Sward surface height (cm) & 15.3 & 19.7 & 24.7 & 0.06 \\
Foliage area index & $1.82 \mathrm{c}$ & $2.48 \mathrm{~b}$ & $2.84 \mathrm{a}$ & 0.028 \\
Foliage angle (degree) & $61.4 \mathrm{a}$ & $57.7 \mathrm{~b}$ & $55 \mathrm{c}$ & 0.45 \\
& & Pre-cut & \\
Light interception (\%) & 95.1 & 95.1 & 95.0 & 0.11 \\
Sward surface height (cm) & 28.1 & 28.2 & 28.5 & 0.13 \\
Foliage area index & 3.82 & 3.80 & 3.78 & 0.051 \\
Foliage angle (degree) & 46.3 & 46.7 & 47.7 & 0.56 \\
\hline
\end{tabular}

SEM = standard error of the mean.

Means followed by the same letter in line do not differ $(\mathrm{P}>0.05)$ by t-Student test.
Table 2 - Post and pre-cutting sward structure in xaraes palisadegrass cut at different heights reaching 95\% of light interception in two seasons of the year

\begin{tabular}{lccc}
\hline Variable & \multicolumn{2}{c}{ Season } & SEM \\
\cline { 2 - 3 } & Summer & $\begin{array}{c}\text { Autumn-winter- } \\
\text { early spring }\end{array}$ \\
\hline & & Post-cut \\
Light interception (\%) & $81.1 \mathrm{~b}$ & $83.7 \mathrm{a}$ & 0.53 \\
Sward surface height (cm) & 20.0 & 19.7 & 0.08 \\
Foliage area index & $2.30 \mathrm{~b}$ & $2.45 \mathrm{a}$ & 0.026 \\
Foliage angle (degree) & $56.7 \mathrm{~b}$ & $59.4 \mathrm{a}$ & 0.049 \\
& & Pre-cut & \\
Light interception (\%) & 95.0 & 95.1 & 0.07 \\
Sward surface height (cm) & 28.4 & 28.1 & 0.15 \\
Foliage area index & 3.81 & 3.79 & 0.030 \\
Foliage angle (degree) & 47.4 & 46.3 & 0.46 \\
\hline
\end{tabular}

SEM $=$ Standard error of the mean

Means followed by the same letter in line do not differ $(\mathrm{P}>0.05)$ by $\mathrm{t}$-Student test.

the plants in a period characterized by low resource availability (rainfall and day light length) because a higher foliage angle allows a more efficient distribution of light inside the sward (Souza Júnior, 2007). The largest foliage angle associated with the greatest remaining foliage area index in autumn-winter-early spring determined an increase in the post-cutting light interception (Table 2), which was probably greater in response to the accumulation of dead material in the plots.

The sward surface height, foliage area index, and foliage angle were not affected by the cutting height and season of the year $(\mathrm{P}>0.05)$ (Tables 1 and 2$)$. This result can be explained because the defoliation frequency (moment for interrupting regrowth) was the same, 95\% of light interception. According to the literature (Da Silva et al., 2009; Difante et al., 2009a, b; Giacomini et al., 2009a, b), this moment precedes the intense competition for light, demonstrating flexibility and adjustment capacity of plants, aiming to optimize the use of incident radiation, therefore, its foliage area. The condition of $95 \%$ of light interception was reached at an average sward surface height of $28.5 \mathrm{~cm}$, a result very close to that observed by Pedreira et al. (2007) $(29.5 \mathrm{~cm})$, when evaluating the same grass species.

As revealed in recent studies with tropical grasses (Carnevalli et al., 2006; Barbosa et al., 2007; Pedreira et al., 2007; Trindade etal., 2007; Difante et al., 2009a, b), particularly with the genera Brachiaria and Panicum, there is a strong relationship between sward surface height and light interception, which indicates the potential of using sward surface height as a cutting/grazing management criterion, similarly to the management of temperate climate grasses (Hodgson, 1990; Hodgson \& Da Silva, 2002). 
Autumn is characterized by a reduction in growth and development conditions of the plants, markedly by a decrease in temperatures and water soil balance (Figures 1 and 2). As a result, there was a reduction in the leaf elongation rate (Table 4), and in the final leaf blade length (Table 3), and an increase in the leaf lifespan, number of live leaves per tiller and leaf senescence rate (Table 4). These changes in tiller morphogenetic/structural traits are highly influenced by the availability of growth factors, mainly temperature and nitrogen (Duru \& Ducrocq, 2000). Therefore, as a strategy of economy of resources, plants reduce their growth rates to minimize injuries caused by stressful conditions.

It is noteworthy that a leaf lifespan of 80.2 days allows a long period of accumulation and storage of leaves, which could be available to the animals in unfavorable climatic periods for forage production. This could be interesting for deferred grazing system. However, it is important to note that several characteristics determine the ability of the plant to be deferred (Fonseca \& Santos, 2009). Thus, despite being promising for use in deferred pastures, xaraes palisadegrass still needs to be evaluated for this purpose.

The tiller population density (Table 4) was approximately $18 \%$ higher in the autumn. In February 2007, there was a

Table 3 - Final leaf blade length (centimeters) in xaraes palisadegrass cut at different heights reaching $95 \%$ of light interception in two seasons of the year

\begin{tabular}{lccc}
\hline Season & \multicolumn{3}{c}{ Cutting height $(\mathrm{cm})$} \\
\cline { 2 - 4 } & 15 & 20 & 25 \\
\hline \multirow{2}{*}{ Summer } & $12.2 \mathrm{Aa}$ & $11.2 \mathrm{Ba}$ & $11.2 \mathrm{Ba}$ \\
& $(0.25)$ & $(0.25)$ & $(0.25)$ \\
Autumn & $9.5 \mathrm{Bb}$ & $10.0 \mathrm{ABb}$ & $10.7 \mathrm{Aa}$ \\
& $(0.25)$ & $(0.25)$ & $(0.25)$ \\
\hline
\end{tabular}

Means followed by the same lowercase letter in the column and capital letter in the line do not differ $(\mathrm{P}>0.05)$ by $\mathrm{t}$-Student test.

Numbers in parentheses corresponded to the standard error of the mean interaction.

Table 4 - Morphogenetic and structural characteristics in xaraes palisadegrass cut at different heights reaching 95\% of light interception in two seasons of the year

\begin{tabular}{lccc}
\hline Variable & \multicolumn{2}{c}{ Season } & SEM \\
\cline { 2 - 3 } & Summer & Autumn & \\
\hline Leaf elongation rate (cm/tiller.day) & $1.54 \mathrm{a}$ & $1.13 \mathrm{~b}$ & 0.034 \\
Leaf appearance rate (leaf/tiller.day) & 0.0677 & 0.0693 & 0.00269 \\
Phyllochron (days/leaf) & 15.0 & 14.9 & 0.53 \\
Number of live leaves (leaves/tiller) & $4.73 \mathrm{~b}$ & $5.40 \mathrm{a}$ & 0.047 \\
Leaf lifespan (days/leaf) & $70.8 \mathrm{~b}$ & $80.2 \mathrm{a}$ & 2.44 \\
Leaf senescence rate (cm/tiller.day) & $0.176 \mathrm{~b}$ & $0.358 \mathrm{a}$ & 0.0358 \\
Stem elongation rate (cm/tiller.day) & 0.066 & 0.059 & 0.0025 \\
Tiller density (tillers/m²) & $699 \mathrm{~b}$ & $825 \mathrm{a}$ & 25.9 \\
\hline
\end{tabular}

SEM = standard error of the mean.

Means followed by the same letter in line do not differ $(\mathrm{P}>0.05)$ by $t$-Student test. strong water deficit (Figure 2), which could have determined a lower tiller population density in the summer. Moreover, in late February, a nitrogen fertilization was carried out, which in addition to the positive water soil balance, must have stimulated tillering (Davies, 1971; Langer, 1979), increasing the tiller population density during that period.

The response of grasses to defoliation has as its main purpose the restoration and maintenance of the growth pattern, inasmuch as the resources are used in a balanced fashion for the optimal plant growth (Lemaire \& Chapman, 1996). Throughout the regrowth period, competition for light increases gradually, reducing both quantity and quality of light that reaches the interior of the sward, determining morphophysiological modifications in the plants. However, when the forage is harvested at 95\% of light interception, intense competition for light is avoided, reducing the accumulation of stems and senescent material.

The cutting height of $25 \mathrm{~cm}$ resulted in higher stem elongation rate (Table 5) when compared to the other treatments. At this height, the light interception at the beginning of regrowth was $90 \%$. Even though the competition for light was still low, the plants cut at $25 \mathrm{~cm}$ remained in a more competitive environment than the ones cut at 15 and $20 \mathrm{~cm}$, which might have resulted in greater stem elongation rate. Besides, cuts at $25 \mathrm{~cm}$ removed a small forage amount (3.5 $\mathrm{cm}$ or around $15 \%)$ because the time of defoliation coincided with a height of $28.5 \mathrm{~cm}$. Probably, under this condition, most growing points of plants were not removed, which also contributed to a greater stem elongation rate.

Table 5 - Morphogenetic and structural characteristics in xaraes palisadegrass cut at different heights reaching $95 \%$ of light interception

\begin{tabular}{|c|c|c|c|c|}
\hline \multirow[t]{2}{*}{ Variable } & \multicolumn{3}{|c|}{ Cutting height $(\mathrm{cm})$} & \multirow[t]{2}{*}{ SEM } \\
\hline & 15 & 20 & 25 & \\
\hline $\begin{array}{l}\text { Leaf elongation rate } \\
\text { (cm/tiller.day) }\end{array}$ & $1.50 \mathrm{a}$ & $1.20 \mathrm{~b}$ & $1.30 \mathrm{~b}$ & 0.041 \\
\hline $\begin{array}{l}\text { Leaf appearance rate } \\
\text { (leaf/tiller.day) }\end{array}$ & 0.0753 & 0.0671 & 0.0631 & 0.00333 \\
\hline Phyllochron (days/leaf) & 13.6 & 15.2 & 16.1 & 0.65 \\
\hline $\begin{array}{l}\text { Number of live leaves } \\
\text { (leaves/tiller) }\end{array}$ & 5.19a & $5.11 \mathrm{ab}$ & $4.92 b$ & 0.052 \\
\hline Leaf lifespan (days/leaf) & 70.3 & 77.5 & 78.7 & 2.99 \\
\hline $\begin{array}{l}\text { Leaf senescence rate } \\
(\mathrm{cm} / \text { tiller.day) }\end{array}$ & 0.256 & 0.292 & 0.253 & 0.0313 \\
\hline $\begin{array}{l}\text { Stem elongation rate } \\
\text { (cm/tiller.day) }\end{array}$ & $0.056 \mathrm{~b}$ & $0.048 \mathrm{~b}$ & $0.083 a$ & 0.0031 \\
\hline $\begin{array}{l}\text { Tiller population density } \\
\text { (tillers } / \mathrm{m}^{2} \text { ) }\end{array}$ & 739 & 797 & 750 & 22.4 \\
\hline
\end{tabular}

SEM = standard error of the mean.

Means followed by the same letter in line do not differ $(\mathrm{P}>0.05)$ by t-Student test. 
There was no cutting height effect for leaf appearance rate, leaf senescence rate, phyllochron, leaf lifespan, tiller population density (Table 5), and final leaf blade length (Table 3). Montagner (2007), studying guinea grass cv. Mombaca submitted to grazing severities, reported no marked differences in morphogenetic and structural characteristics among the grazing heights evaluated. These data are corroborated by those obtained by Sousa et al. (2010), indicating that the frequency of defoliation can be more determining in changing patterns of morphogenetic and structural characteristics of the tillers than severity.

Nevertheless, leaf elongation rate and the number of live leaves per tiller were higher for the cutting height of $15 \mathrm{~cm}$ (Table 5). Cutting heights of $15 \mathrm{~cm}$ removed a greater amount of forage, determining the appearance of younger tillers at this height, and, consequently, a higher leaf tissue renewal. Barbosa (2004) and Paiva (2009) reported that the age of tillers has a strong influence on their morphogenetic and structural characteristics, resulting in a progressive loss of vigor as the age of the tillers increases.

\section{Conclusions}

The interception of 95\% of incident light by xaraes palisadegrass coincides with a sward surface height of about $30 \mathrm{~cm}$, regardless of the severity of defoliation or season of the year. The morphogenetic and structural characteristics of xaraes palisadegrass are more influenced by the seasons of the year than by the severity of defoliation. Under intermittent defoliation conditions, xaraes palisadegrass can be cut when the residual height is close to $15 \mathrm{~cm}$.

\section{Acknowledgements}

To CNPq and to the Departamento de Zootecnia of the Universidade Federal de Viçosa for the opportunity and sponsorship of the first author. Thanks are also to: Marta Deysiane Alves Faria, Salim Jacaúna de Souza Júnior, Karina Ellen Matias de Oliveira, Rodrigo Soares Ramos, Filipe Velten Silva, and Felipe Borges Carneiro, for their help in carrying out the research project.

\section{References}

BARBOSA, R.A. Características morfofisiológicas e acúmulo de forragem em capim-tanzânia (Panicum maximum Jacq. cv. Tanzânia) submetido a frequências e intensidades de pastejo. 2004. 100f. Tese (Doutorado em Zootecnia), Universidade Federal de Viçosa, Viçosa, MG.
BARBOSA, R.A.; NASCIMENTO JÚNIOR, D.; EUCLIDES, V.B.P et al. Capim-tanzânia submetido a combinações entre intensidade e frequência de pastejo. Pesquisa Agropecuária Brasileira, v.42, n.3, p.329-340, 2007.

BRAGA, G.J.; PORTELA, J.N.; PEDREIRA, C.G.S. et al. Crescimento de folhas e hastes durante a rebrotação de Brachiaria decumbens sob efeito de intensidade e frequência de pastejo. In: REUNIÃO ANUAL DA SOCIEDADE BRASILEIRA DE ZOOTECNIA, 45., 2008, Lavras. Anais... Lavras: SBZ, 2008. (CD-ROM).

CARNEVALLI, R.A.; DA SILVA, S.C.; BUENO, A.A.O. et al. Herbage production and grazing losses in Panicum maximum cv. Mombaça under four grazing managements. Tropical Grasslands, v.40, p.165-176, 2006.

DA SILVA, S.C.; BUENO, A.A.O.; CARNEVALLI, R.A. et al. Sward structural characteristics and herbage accumulation of Panicum maximum cv. Mombaça subjected to rotational stocking managements. Scientia Agricola, v.66, n.1, p.8-19, 2009.

DA SILVA, S.C.; NASCIMENTO JÚNIOR, D. Avanços na pesquisa com plantas forrageiras tropicais em pastagens: características morfofisiológicas e manejo do pastejo. Revista Brasileira de Zootecnia, v.36, n.4, p.121-138, 2007 (supl. especial).

DAVIES, A. Changes in growth rate and morphology of perennial ryegrass swards at hight and low nitrogen levels. Journal of Agricultural Science, v.77, p.123-134, 1971.

DIFANTE, G.S; EUCLIDES, V.P.B.; NASCIMENTO JÚNIOR, D. et al. Ingestive behaviour, herbage intake and grazing efficiency of beef cattle steers on Tanzania guineagrass subjected to rotational stocking managements. Revista Brasileira de Zootecnia, v.38, n.6, p.1001-1008, 2009b.

DIFANTE, G.S; NASCIMENTO JÚNIOR, D.; EUCLIDES, V.P.B. et al. Sward structure and nutritive value of tanzania guineagrass subjected to rotational stocking managements. Revista Brasileira de Zootecnia, v.38, n.1, p.9-19, 2009a.

DURU, M.; DUCROCQ, H. Growth and senescence of the successive grass leaves o a tiller ontogenic development and effect of temperature. Annals of Botany, v.85, p.635-643, 2000.

EMPRESA BRASILEIRA DE PESQUISA AGROPECUÁRIA EMBRAPA. Serviço Nacional de Levantamento e Conservação de Solos. Sistema brasileiro de classificação de solos. 2.ed. Rio de Janeiro: Embrapa Solos, 2006. 306p.

FONSECA, D.M.; SANTOS, M.E.R. Diferimento de pastagens: Estratégias e ações de manejo. In: SIMPÓSIO DE FORRAGICULTURA E PASTAGEM, 6.; CONGRESSO DE FORRAGICUlTURA E PASTAGEM, 3., 2009, Lavras. Anais... Lavras: UFLA, 2009. p.65-88.

GIACOMINI, A.A.; DA SILVA, S.C.; SARMENTO, D.O.L. et al. Components of the leaf area index of marandu palisadegrass swards subjected to strategies of intermittent stocking. Scientia Agricola, v.66, n.6, p.721-732, 2009a.

GIACOMINI, A.A.; DA SILVA, S.C.; SARMENTO, D.O.L. et al. Growth of marandu palisadegrass subjected to strategies of intermittent stocking. Scientia Agricola, v.66, n.6, p.733-741, 2009b.

HODGSON, J. Grazing management: science into practice. New York: John Wiley and Sons, 1990. 203p.

HODGSON, J.; DA SILVA, S.C. Options in tropical pasture management. In: REUNIÃO ANUAL DA SOCIEDADE BRASIlEIRA DE ZOOTECNIA, 39., 2002, Recife. Anais... Recife: SBZ, 2002. p.180-202.

KORTE, C.J.; WATKIN, B.R.; HARRIS, W. Use of residual leaf area index and light interception as criteria for spring-grazing management of a ryegrass-dominant pasture. New Zealand Journal of Agricultural Research, v.25, p.309-319, 1982.

LANGER, R.H.M. Tillering. In: LANGER, R.H.M. (Ed.). How grasses grow. London: Edward Arnold, 1979. chap.5, p.19-25.

LEMAIRE, G.; CHAPMAN, D. Tissue flows in grazed plant communities. In: HODGSON, J.; ILLIUS, A.W. (Eds.). The 
ecology and management of grazing systems. Wallingford: CAB International, 1996. p.3-36.

LITTEL, R.C.; PENDERGAST, J.; NATARAJAN, R. Modelling covariance structure in the analysis of repeated measures data. Statistics in Medicine, v.19, p.1793-1819, 2000.

MARSHALL, C. Physiological aspects of pasture growth. In: SNAYDON, R.W. (Ed.). Managed grasslands: analytical studies ecosystems of the world. Amsterdam: Elsevier Science Publishers B.V., 1987. cap.4, p.29-46.

MONTAGNER, D.B. Morfogênese e acúmulo de forragem em capim-mombaça submetido a intensidades de pastejo rotativo. 2007. 60f. Tese (Doutorado em Zootecnia) Universidade Federal de Viçosa, Viçosa, MG.

PAIVA, A.J. Características morfogênicas e estruturais de faixas etárias de perfilhos em pastos de capim-marandu submetidos à lotação contínua e ritmos morfogênicos contrastantes. 2009. 104f. Dissertação (Mestrado em Ciência Animal e Pastagens) - Escola Superior de Agricultura "Luiz de Queiroz”/Universidade de São Paulo, Piracicaba.

PEDREIRA, B.C. Interceptação de luz, arquitetura e assimilação de carbono em dosséis de capim-xaraés [Brachiaria brizantha (A. Rich.) Stapf. cv. Xaraés] submetidos a estratégias de pastejo rotacionado. 2006. 86f. Dissertação (Mestrado em Agronomia - Ciência Animal e Pastagens) - Escola Superior de Agricultura "Luiz de Queiroz"/ Universidade de São Paulo, Piracicaba.

PEDREIRA, B.C.; PEDREIRA, C.G.S.; DA SILVA, S.C. Estrutura do dossel e acúmulo de forragem de Brachiaria brizantha cv. Xaraés em resposta a estratégias de pastejo. Pesquisa Agropecuária Brasileira, v.42, n.2, p.281-287, 2007.
RAIJ, B.V.; QUAGGIO, J.A.; SILVA, N.M. Extraction of phosphorus, potassium, calcium, and magnesium from soils by ion-exchange resin procedure. Communications in Soil Science and Plant Analysis, v.17, n.5, p.547-566, 1986.

SOUSA, B.M.L.; NASCIMENTO JÚNIOR, D.; DA SILVA, S.C. et al. Structural and morphogenetic characteristics of andropogon grass submitted to different cutting heights. Revista Brasileira de Zootecnia, v.39, n.10, p.2141-2147, 2010

SOUZA JÚNIOR, S.J. Estrutura do dossel, interceptação de luz e acúmulo de forragem em pastos de capimmarandu submetidos a estratégias de pastejo rotativo por bovinos de corte. 2007. 122f. Dissertação (Mestrado em Ciência Animal e Pastagens) - Escola Superior de Agricultura “Luiz de Queiroz”/Universidade de São Paulo, Piracicaba.

THORNTHWAITE, C.W.; MATHER, R.J. The water balance. New Jersey: Laboratory of Climatology, v.8, 1955. 104p.

TRINDADE, J.K.; DA SILVA, S.C.; SOUZA JÚNIOR, S.J. et al. Composição morfológica da forragem consumida por bovinos de corte durante o rebaixamento do capim-marandu submetido a estratégias de pastejo rotativo Pesquisa Agropecuária Brasileira, v.42, n.6, p.883-890, 2007.

VALLE, C.B.; JANK, L.; RESENDE, R.M.S.; BONATO, A.L.V. Lançamento de cultivares forrageiras: o processo e seus resultados - cvs. Massai, Pojuca, Campo Grande e Xaraés. In: NÚCLEO DE ESTUDOS EM FORRAGICULTURA, 4., 2003, Lavras. Anais... Lavras: UFLA, 2003. p.179-225.

WOLFINGER, R.D. Covariance structure selection in general mixed models. Communications in Statistics Simulation and Computation, v.22, n.4, p.1079-1106, 1993. 